\title{
Mengejar Pekerjaan Impian: Pelatihan Daring Membuat Curriculum Vitae dan Cover Letter
}

\author{
Eugenius Tintus Reinaldi, Christa Vidia Rana Abimanyu \\ Univeristas Katolik Soegijapranata \\ eugeniusreinaldi@unika.ac.id \\ cvr_abimanyu@unika.ac.id
}

\begin{abstract}
Freshly graduated students are expected to get a job soon, but the competition in the jobseeking world is getting tougher because the number of fresh-graduate continues to increase from year to year. The first stage of employee selection is administrative selection, which can be done from Curriculum Vitae and Cover Letter sent by applicants. Considering that this first stage is crucial for determining the next stage, $C V$ and CL must be made seriously and with consideration. This training aims to provide provisions in the form of strategies for making $C V$ and $C L$ for students who have just graduated from college. The training was attended by 27 students who are currently taking thesis courses and those who have finished their thesis trial using the online method using cyber.unika.ac.id. The training participants had a positive reaction to this training. In addition, their skills in making $C V$ and $C L$ have also improved, seen from the $C V$ and $C L$ results that were collected by the participants after the training ended.
\end{abstract}

Keywords: cover letter, curriculum vitae, job-seeker, online training

\begin{abstract}
Abstrak: Mahasiswa yang baru lulus diharapkan untuk segera mendapat pekerjaan, namun persaingan di dunia kerja semakin ketat karena jumlah mahasiswa yang lulus terus meningkat dari tahun ke tahun. Tahap pertama dari seleksi calon karyawan adalah seleksi administratif, yang bisa dilihat dalam Curriculum Vitae dan Cover Letter yang dikirimkan oleh pelamar kerja. Mengingat tahap pertama ini sangat krusial untuk menentukan tahap selanjutnya, maka CV dan CL harus dibuat dengan serius dan penuh pertimbangan. Oleh karena itu, pelatihan ini bertujuan memberikan bekal berupa strategi membuat CV dan CL untuk mahasiswa yang baru lulus kuliah. Pelatihan diikuti oleh 27 orang mahasiswa yang sedang mengambil mata kuliah skripsi maupun yang sudah selesai sidang skripsi dengan metode daring menggunakan cyber.unika.ac.id. Peserta pelatihan memiliki reaksi yang positif terhadap pelatihan ini. Selain itu, keterampilan mereka dalam membuat CV dan CL juga meningkat, dilihat dari hasil CV dan CL yang dikumpulkan peserta setelah pelatihan berakhir.
\end{abstract}

Kata kunci: curriculum vitae, pelatihan daring, pencari kerja, surat lamaran kerja

\section{PENDAHULUAN}

Setelah menyelesaikan pendidikan formal selama kurang lebih 16 tahun, seseorang memiliki harapan untuk segera mendapatkan kerja dan memulai karir. Seorang Sarjana tentu ingin mendapatkan penghasilan sendiri dan bisa hidup dengan mandiri, sesuai dengan tugas-tugas perkembangan fase dewasa awal untuk mulai bekerja, menerima tanggung jawab sebagai warga negara, serta memulai dan membina keluarga (Monks, Knoers, \& Haditono, 2014). 
Menurut data yang dilansir dari PDDikti, jumlah lulusan dari Perguruan Tinggi cenderung terus meningkat sejak tahun ajaran 2012/2013 sampai dengan 2017/2018. Mulai dari 807.319 orang di tahun 2012/2013, hingga 1.113 .375 di 2017/2018 (PDDikti Kementerian Riset, Teknologi, dan Perguruan Tinggi, 2018). Ironisnya, menurut data dari Badan Pusat Statistik, angka pengangguran lulusan Diploma I/II/III serta universitas cenderung meningkat sejak tahun 2017 (Pusparisa, 2019).

Data-data tersebut menunjukkan bahwa persaingan dalam dunia kerja sangatlah ketat. Oleh karena itu, para lulusan baru perlu memiliki strategi supaya bisa dilirik oleh perusahaan atau pemberi kerja. Perusahaan atau pemberi kerja tentu mengharapkan mereka dapat merekrut talenta-talenta terbaik untuk bergabung dengan organisasi mereka. Sehingga mereka akan melakukan proses rekrutmen dan seleksi untuk memastikan hanya talenta terbaik yang akan bergabung dengan mereka.

Rekrutmen adalah proses dari perusahaan dalam menarik perhatian pelamar kerja (Riggio, 2013). Salah satu ukuran keberhasilannya adalah apabila proses rekrutmen yang dilakukan dapat menarik perhatian sejumlah besar talenta yang berkualitas dan cocok dengan kebutuhan organisasi. Metode rekrutmen sendiri ada berbagai macam, mulai dari yang konvensional seperti menggunakan iklan lowongan pekerjaan di koran maupun selebaran yang disebar di tempat-tempat strategis (seperti di universitas atau di SMK), jobfair, televisi, radio, hingga dengan menggunakan internet, seperti linkedin, jobstreet, dan sebagainya.

Selanjutnya tugas perusahaan pemberi kerja adalah melakukan seleksi terhadap lamaran yang masuk. Robbins \& Judge (2013) menjelaskan proses seleksi dimulai dari seleksi awal, dengan tujuan untuk menyaring pelamar kerja agar yang lolos ke tahap selanjutnya hanya yang benar-benar memenuhi persyaratan dasar yang disyaratkan, bisa dilakukan dengan melihat Curriculum Vitae maupun Cover Letter (surat lamaran kerja), serta pemeriksaan latar belakang. Selanjutnya untuk pelamar yang lolos akan ke tahap seleksi substansif, dimana pada tahap ini hanya pelamar yang benar-benar kompeten yang bisa lolos ke tahap berikutnya, yaitu seleksi tahap akhir, dengan tujuan untuk melakukan cek sebelum menawarkan pekerjaan kepada pelamar kerja yang memenuhi syarat.

$$
\text { Mempertimbangkan }
$$
proses rekrutmen dan seleksi yang dilakukan oleh pemberi kerja, maka para pencari kerja perlu mengetahui berbagai macam strategi 
Patria : Jurnal Pengabdian Kepada Masyarakat

ISSN : 2656-5455 (media online) Vol. 3 | No. 1 Maret 2021

untuk bisa melewati tahapan dalam proses rekrutmen dan seleksi pekerjaan. Seleksi administrasi dengan melihat $\mathrm{CV}$ dan $\mathrm{CL}$ adalah tahap pertama yang dilakukan oleh sebuah perusahaan. Oleh karena itu, menyusun $\mathrm{CV}$ dan $\mathrm{CL}$ adalah hal yang penting. Dengan CV dan CL yang menonjol, seorang pencari kerja dapat mempromosikan dirinya di mata perusahaan, sehingga dapat meningkatkan peluang dirinya agar dapat dipanggil untuk melewati tahap seleksi selanjutnya.

\section{METODE PELAKSANAAN} PENGABDIAN

Pengabdian ini menggunakan pendekatan kelompok melalui pelatihan. Metode pelatihan dipilih karena cara ini dapat meningkatkan pengetahuan (knowledge), dan keterampilan (skill).

Peserta adalah 27 orang mahasiswa Fakultas Psikologi Unika Soegijapranata yang sedang menyusun skripsi atau yang baru saja lulus skripsi (sedang menunggu jadwal wisuda). Pelatihan ini didesain secara daring melalui cyber.unika.ac.id.

Serangkaian pelatihan mulai dari ceramah interaktif, ice breaking, diskusi dalam kelompok kecil, diskusi umum, hingga presentasi tugas sebagai evaluasi keberhasilan pelatihan dilakukan melalui fitur Big Blue Button yang diakses dari laman cyber.unika.ac.id. Sementara presensi peserta dilakukan dengan menggunakan menu attendance pada laman cyber.unika.ac.id.

Pelatihan dibagi menjadi dua sesi, yang masing-masing berjalan selama 120 menit. Sesi pertama berlangsung pada 14 Mei 2020. Sesi ini terdiri dari tiga topik yaitu gambaran umum mengenai rekrutmen dan seleksi kerja sebagai materi pembuka pelatihan, dilanjutkan dengan gambaran umum mengenai $\mathrm{CV}$ serta teknik penyusunannya, serta diakhiri dengan gambaran umum mengenai CL serta teknik penyusunannya.

Topik pertama mengenai rekrutmen dan seleksi kerja dibahas dengan ceramah interaktif. Melalui topik ini peserta sadar bahwa mereka berada dalam sebuah kompetisi dengan banyak kompetitor dari universitas lain. Peserta juga dapat mengerti bahwa hal tersebut dilakukan oleh perusahaan supaya dapat memastikan bahwa karyawan yang telah lolos seleksi benar-benar memiliki kualifikasi yang diperlukan dan cocok bekerja di perusahaan tersebut. Di akhir topik ini peserta menjadi sadar bahwa CV dan CL perlu disusun dengan serius, karena dua hal tersebut adalah representasi diri mereka yang pertama kali diterima dan dipertimbangkan perusahaan yang dilamar.

Topik kedua mengenai CV serta penyusunannya dilakukan dengan metode 
Patria : Jurnal Pengabdian Kepada Masyarakat

ISSN : 2656-5455 (media online) Vol. 3 | No. 1 Maret 2021

roleplay dan diskusi. Peserta diminta juga mengevaluasi sejauh mana berperan sebagai HRD yang bertugas mengomentari dan menyeleksi $\mathrm{CV}$ yang masuk. Melalui roleplay peserta memiliki kesempatan berada dalam sisi perusahaan, dan memahami apa yang sebenarnya penting. Melalui aktivitas tersebut peserta mengerti bahwa materi, penyampaian, dan desain merupakan hal yang perlu diperhatikan dalam penyusunan CV. Selain itu elemen seperti data diri dan kontak, riwayat pendidikan, pengalaman kerja atau organisasi, keterampilan yang relevan, referensi, dan foto diri juga perlu dimasukkan ke dalam $\mathrm{CV}$, dengan memperhatikan 3 hal inti tadi.

Topik ketiga mengenai surat lamaran kerja (cover letter/CL) serta penyusunannya juga dilakukan dengan metode roleplay dan diskusi. Peserta berperan sebagai HRD yang mengomentari dan menyeleksi CL. Dalam aktivitas tersebut peserta memahami format penulisan CL yang baik, penggunaan bahasa, hingga hal detail seperti pemilihan font yang baik. Sesi hari pertama diakhiri dengan tanya jawab dan penugasan untuk membuat CV dan CL pada para peserta.

Sesi hari kedua terlaksana di hari berikutnya, 15 Mei 2020. Sesi ini membahas tugas yang diberikan di hari pertama. Pembahasan ini selain berfungsi untuk memperdalam pengetahuan peserta, pemahaman baru yang diserap peserta dalam pelatihan ini. Sesi Kedua dilakukan dengan metode diskusi, sehingga dapat memfasilitasi mahasiswa untuk saling memberi masukan dan komentar.

Diskusi dilakukan dalam dua cara, yang pertama adalah dengan menggunakan Breakout Room, salah satu fasilitas dalam Big Blue Button yang memungkinkan peserta untuk berkumpul dalam kelompok kecil. Cara ini digunakan untuk berdiskusi dan membahas contoh CV dan CL yang dibuat oleh peserta pelatihan dalam kelompok kecil. Selanjutnya pembahasan dilakukan dalam kelompok besar, pelatih menampilkan salah satu CV dan CL dari peserta, lalu meminta masukan dari peserta lainnya. Setelah itu tim pelatih juga turut memberikan masukan.

\section{HASIL PENGABDIAN}

Peserta memiliki reaksi positif terhadap pelatihan ini. Ada rasa senang dengan metode baru yang memungkinkan peserta mendapat pelatihan dan mempelajari keterampilan baru dari lokasi mereka masing-masing tanpa harus bertemu.

Peserta merasa memiliki pengetahuan dan kemampuan baru dalam menyusun $\mathrm{CV}$ dan CL. Sebelumnya, peserta tidak memahami bahwa CV dan CL 
adalah hal penting dan perlu dikerjakan dengan serius. Setelah mengikuti pelatihan ini mereka memahami bahwa banyak hal yang harus diperhatikan agar CV dan CL yang dibuat dapat menyampaikan pesan secara efektif.

Disamping proses pelatihan, peserta juga merasa terbantu oleh modul pegangan yang mereka miliki. Modul tersebut membantu mereka mengingat poin penting dalam pelatihan sehingga saat praktek membuat CV dan CL dapat lebih lancar.

Dalam pelaksanaan pelatihan, peserta memberikan catatan mengenai proses pelatihan yang sempat tersendat karena jaringan. Apalagi ada satu peserta yang kesulitan untuk bergabung karena masalah jaringan internet, pada akhirnya ia memutuskan untuk tidak mengikuti sesi hari kedua secara live.

Secara keseluruhan, seluruh peserta terlibat aktif dalam pelatihan ini. Satu peserta yang bermasalah dengan jaringan internet memutuskan untuk belajar dari rekaman Big Blue Button dan modul yang telah dibagikan sebelumnya, sehingga ia pun mendapat pengetahuan yang sama dengan peeserta lainnya. Setelah pelatihan usai pelatih memberikan kesempatan kepada peserta pelatihan untuk mengirimkan $\mathrm{CV}$ dan CLnya. Pelatih kemudian memberikan tanggapan, saran, dan masukan atas $\mathrm{CV}$ dan $\mathrm{CL}$ yang dikirimkan tersebut.

\section{SIMPULAN}

Pelatihan ini berjalan dengan lancar dan memiliki dampak yang positif pada peserta. Pertama pada level reaksi, peserta memiliki emosi positif dalam pelatihan ini. Emosi positif dalam pelaksanaan pelatihan selanjutnya akan membantu peserta memahami materi yang diberikan. Kedua pada level pengetahuan, peserta memahami materi dengan baik, yang dibuktikan dari hasil penyusunan $\mathrm{CV}$ dan $\mathrm{CL}$ setelah pelatihan berakhir. Disamping proses pelatihan, Modul yang disusun juga dapat membantu peserta dalam memahami materi.

Modul pelatihan yang telah disusun untuk pelatihan ini dapat digunakan lagi untuk pelatihan dengan tema yang sama. Sehingga, mengingat hasil pelatihan ini memberikan dampak yang positif pada peserta, pelatihan serupa dapat diselenggarakan lagi dengan peserta yang lebih beragam.

Hal yang perlu menjadi perhatian dalam pelatihan daring seperti ini adalah perihal kesiapan sarana dan prasarana, baik dari peserta maupun pelatih. Sehingga untuk pelatihan daring selanjutnya, hal-hal yang sifatnya teknis seperti kecepatan internet yang stabil, menjadi sesuatu yang 
Patria : Jurnal Pengabdian Kepada Masyarakat

harus jadi perhatian. Kalau perlu sejak awal

pelatih sudah menentukan jaringan dan kuota minimum yang diperlukan untuk mengikuti pelatihan, sehingga peserta dapat mempersiapkan diri dengan sebaik mungkin.

\section{DAFTAR PUSTAKA}

Monks, F., Knoers, A., \& Haditono, S. (2014). Psikologi perkembangan: Pengantar dalam berbagai bagiannya. Yogyakarta: Gadjah Mada University Press.

PDDikti Kementerian Riset, Teknologi, dan Perguruan Tinggi. (2018). Statistik pendidikan tinggi 2018. Jakarta: Pusdatin Kemenristekdikti.

Pusparisa, Y. (2019, Mei 17). Infografik Katadata.co.id. Dipetik Maret 5, 2020, dari katadata.co.id: https://katadata.co.id/infografik/201 9/05/17/angka-pengangguranlulusan-perguruan-tinggimeningkat
Riggio, R. E. (2013). Introduction to industrial/organizational psychology (6th ed.). New Jersey: Pearson.

Robbins, S., \& Judge, T. (2013). Organizational behavior (15th ed.). New Jersey: Pearson Education, Inc. 